KÓSA GÁBOR

\title{
A Dhammacakkappavattana-sutta egyik korai kínai fordítása (T02n0109)
}

Jelen tanulmányban egy rövid kínai buddhista szöveg fordítását és értelmezését adom közre. ${ }^{1}$ A szöveg érdekessége, hogy a történeti Buddha legelsőként számontartott és egyik legfontosabb beszédének, a Dharma-kerék megforgatásának valószínűleg legkorábbi kínai fordítása. ${ }^{2}$

\section{A Dhammacakkappavattana-sutta és kínai változatai}

A páli Dhammacakkappavattana-sutta ('A Tan kerekének megforgatása szutta') két helyen jelenik meg a Páli Kánonban, egyszer a „Beszédek kosarának" (Suttapiṭaka) Samyutta-nikāya részében (SN 56.11), ${ }^{3}$ másodjára pedig a „Fegyelmi elöírások kosarának” (Vinayapițaka) Mahāvagga (Mv 1.6.13-14) címü könyvében ${ }^{4}$. A beszédnek számos szanszkrit, kínai és tibeti változata létezik, amelyek elsősorban vinayaszövegek között vagy Buddhaéletrajzokban találhatók. ${ }^{5}$

A beszéd narratív kontextusa szerint megvilágosodása után a történeti Buddha elmegy a Vārāṇas̄i (p. Bārāṇasi) melletti Özparkba (p. Migadāya,

1 Köszönettel tartozom az ELTE BTK 2018/2019-es tanévének tavaszi félévében Ruzsa Ferenccel közösen tartott szemináriumunk (Páli-kínai buddhista szövegolvasás 1.) résztvevőinek: Fenyvesi Boglárkának, Jónás Dávidnak, Jónás Zsoltnak és nem utolsósorban a hozzánk csatlakozó Szegedi Mónikának. Ruzsa Ferencnek, Szegedi Mónikának és Fenyvesi Boglárkának külön köszönöm, hogy jelen tanulmány első változatát elolvasták, kommentálták és kiegészítették. Ruzsa Ferencnek hálás vagyok a páli és a szanszkrit szavakra és kifejezésekre vonatkozóan nyújtott segítségéért. A páli, a szanszkrit és a kínai nyelvü alakokra p., sz. és k. rövidítésekkel hivatkozom. A T a Taishō buddhista kánon kiadására utal (Takakusu-Watanabe 1924-32).

2 Zacchetti 1997: 381.

3 Fordításai: A páli fordítócsoport 2011; Bodhi 2000: 1843-1847.

4 Fordításai: Vekerdi 1989: 45; Horner 1951/1982: 15-18.

5 Anālayo 2017: 373. 
sz. Mrgadāva) ahhoz az öt aszkétához (p. pañcavaggiyāa, sz. pañcakāh, pañcakāh bhadra-vargīyāh, pañcakāh bhadra-vargikāh), akik elhagyták öt, amikor megszakította szigorú aszketikus gyakorlatait. A beszéd egyik célja tehát, hogy a Buddha elmagyarázza és bebizonyítsa, a megszabadulás lehetséges szigorú aszkézis nélkül. ${ }^{6}$ A páli szöveg a két szélsőség (a túlzott érzékiség és a túlzott aszkézis) helyett a középső ösvényt (p. majjhimā pațipadā, sz. madhyamā pratipad) nevezi meg követendőként, majd a „négy nemes igazság" (a szenvedés, eredete, leküzdése és az út igazsága; p. dukkha-, samudaya-, nirodha-, magga-sacca; sz. duhkha-, samudaya-, nirodha-, mārga-satya), illetve ezen belül a „nemes nyolcrétü ösvény” tömör kifejtését tartalmazza. A „négy nemes igazság” mindegyikét három szempontból (p. ti-parivatța, sz. tri-parivarta) közelíti meg a szöveg: 1. az adott igazság tényének rögzítése; 2 . a vele kapcsolatos konkrét teendő megnevezése (sorrendben: felismerni, elvetni, megtapasztalni, gyakorolni); 3. annak megállapítása, hogy a Buddha ezeket elvégezte. Összesen tehát egy tizenkettes rendszert (p. dvādasâkāra, sz. dvādaśâkāra) mutat be. ${ }^{7}$ Az öt aszkéta közül Koṇ̣añña lesz az első, aki megérti a Buddha ezen tanítását, és AñnāsiKoṇ̣añña ('Koṇ̣añña, aki megértetted', sz. Ājñāta Kauṇ̣̣inya) néven válik ismertté. ${ }^{8}$ Ezzel tehát a Dharma kereke mozgásba lendült, és az isteni szférák lakói is konstatálják, hogy ezentúl senki nem lesz képes megállítani a Dharma-kerék forgását. ${ }^{9}$

A Buddha életének narratíváján belül a Tan kerekének megforgatása nyilvánvalóan utal arra a korai jóslatra, amely szerint a gyermek Gautamából vagy világot hódító király (p. cakkavattin, sz. cakravartin, 'kerékforgató'), vagy megvilágosodott személy lesz, ebben az értelemben tehát mindkét jóslat beteljesedett, még ha a kerékforgatónak (mint uralkodónak) nem is az ókori Indiában használt értelmében. ${ }^{10}$

Anālayo 2017: 373.

Anālayo 2017: 373-374; Dessein 2007: 17.

Anālayo 2017: 374.

A párhuzamos szövegekben inkább azon van a hangsúly, hogy senki más nem lett volna képes elindítani a kerék forgását (Anālayo 2017: 374).

10 Például Nidānakathā 150: So sace agāraṃ ajjhāvasissati, rājā bhavissati cakkavattī; sace agārā nikkhamma pabbajissati, buddho bhavissati loke vivatțacchado"ti (Körtvélyesi 2018: 139. n. 322). Ezt a párhuzamot számos hely megerősíti: „Akkor a kuszinárái mallák megkérdezték Ánanda testvértöl: - Hogyan bánjunk az általjutott (tathāgata) testével? - Ugyanúgy, ahogy a 'világuralkodó' (páli: cakkavattin) király testével" (Mahāparinibbāna-sutta [DN 16], idézi Körtvélyesi 2018: 139). A kerék- 
A kínai buddhista kánonban számos változata létezik ennek a beszédnek, és ezek különböző mértékben tartalmazzák azokat az elemeket, amelyek a páli szövegben megtalálhatók. A Bart Dessein által fontosnak talált mozzanatok például egyetlen, általa vizsgált kínai fordításban sincsenek jelen együttesen maradéktalanul. ${ }^{11}$ A Dessein által vizsgált szövegekben az egyetlen motívum, amelyben mindegyik szöveg megegyezik, hogy az első beszéd a Vārānasī melletti Özparkban hangzott el, de még az sem univerzális motívum, hogy kizárólag az öt aszkéta lett volna jelen a beszédnél. ${ }^{12}$ A kínai változatok között van olyan szöveg, amely csak a középutat fejti ki (T26, Ekottarāgama), és van olyan, amelyik éppen ezt a részt hagyja ki (T99, T110), ${ }^{13}$ ismét mások Kauṇdinya megtérését nem említik (T26, T125). ${ }^{14}$

Miközben hatástörténetükben egyes buddhista szövegek sugallhatnak egységes üzenetet, addig keletkezéstörténetükben, úgy tünik, különböző forrásra vezethetők vissza. A négy nemes igazság és a tizenkettes rendszer összekapcsolása André Bareau szerint már az abhidharmikus fejlődésnek köszönhető, ${ }^{15}$ és így nem tekinthető eredetinek, továbbá mindez összefügghet Koṇ̣añña (Kauṇịinya) és az istenek megerősítő megnyilatkozásának a szerepeltetésével, mivel ez utóbbi motívumok éppen ott jelennek meg, ahol a tizenkettes rendszert kifejtik, míg ahol nincs szó a tizenkettes rendszerről, ott Koṇ̣añña és az istenek sem szerepelnek. ${ }^{16}$ B. Dessein úgy véli, hogy Buddha első beszéde valószínűleg csak a két szélsőség elkerüléséről és a középső útról szólt, majd ezután kapcsolták ezt össze a négy nemes igazsággal és a tizenkettes rendszerrel. ${ }^{17}$

forgató királyhoz ,[j]ó megoldásnak tűnik a 'központi király' értelmezés (az Arthaśāstra alapján). A kerék az archaikus hatalmi rendszer metaforája, a középpontjában a központi uralkodóval (rājā cakkavatti), a periférián pedig a föhatalmát elismerő királyokkal, fejedelmekkel, törzsekkel” (Körtvélyesi 2018: 139. n. 321).

Ld. Dessein 2007: 18 táblázatát.

Dessein 2007: 20.

Dessein 2007: 20.

Dessein 2007: 18.

15 Bareau 1963: 180; Dessein 2007: 22. Magának a négy nemes igazságnak kései voltát C. A. F. Rhys Davids vetette fel 1935-ben, a kérdésről és Bareau kritikájáról ld. Anālayo 2012: 28-33.

Dessein 2007: 19, 22.

17 Dessein 2007: 33: "The general picture that emerges from the above analysis is that it is very likely that the first sermon of the Buddha only concerned the two extremes to be avoided and the middle mode of progress. Very early, the concept of the four 
Jelen írásban a T109-es szöveget (Fo shuo zhuan falun jing 佛說轉法 輪經) vizsgálom, amelyet a kínai buddhista hagyomány az egyik legkorábbi fordítónak, a pártus származású An Shigaónak 安世高 (i. sz. 2. sz.) tulajdonít. ${ }^{18}$ An Shigao a hagyomány szerint egy pártus herceg volt, aki a trónról lemondva i. sz. 148-ban érkezett a Keleti Han-kori (i. sz. 25-220) Kína fővárosába, Luoyangba 洛陽, ahol buddhista szövegek fordítójaként tevékenykedett, ${ }^{19}$ alakjához számos legenda kapcsolódott. ${ }^{20}$ I. sz. 374-ben keletkezett katalógusában Dao'an 道安 34 fordítását tartja számon, ${ }^{21}$ de a Tangkorra (i. sz. 618-906) ez a szám már 179-re duzzadt. Ezen fordítások közül E. Zürcher szerint An Shigao valójában mindössze tizenhatot, ${ }^{22} \mathrm{~S}$. Zacchetti szerint pedig csak tizenhármat ${ }^{23}$ készített.

A Dao'an-féle féle 34-es listában már szerepel az általunk vizsgált mü is: „'Megforgatni a Dharma kerekét' [Zhuan falun jing]: egy tekercs (egyesek 'A Dharma-kerék megforgatása'-nak [Falun zhuan jing] nevezik.," ${ }^{24}$ Hozzá kell tenni ugyanakkor, hogy a T109-nek An Shigaóhoz való hozzárendelését többen megkérdőjelezték, E. Zürcher például a következőket írta: „Dao’an An Shigaónak tulajdonítja, de a szövegben olyan stilisztikai jellegzetességek és az írott klasszikus nyelvből (wenyan) származó keveredések vannak, amelyek általában nem jelennek meg An Shigao fordításaiban." ${ }^{25}$ J. Nattier felhívja a figyelmet, hogy Ui Hakuju 宇井伯寿 1971-ben megjelent müvében (Yakukyōshi kenkyū 訳 教史研究) An Shigaót nevezi meg fordítóként, ${ }^{26}$ ugyanakkor Nattier maga ezzel nem ért egyet, problematikusnak tartja ezt a hozzárendelést, ${ }^{27}$ és úgy véli, nem An Shigao, hanem az iskolájához tartozó

truths became linked to this middle mode of progress, and these four noble truths were further developed into the theory of the three cycles and twelve aspects."

Ld. Zürcher 2007: 32-34; Nattier 2008: 38-72.

Zürcher 1977: 177 [2013: 27].

Forte 1995.

Ez a Sengyou 僧祐 által 515-518-ban összeállított Chu sanzang ji ji 出三藏記集 (T55n2145) címü müben maradt fenn (p0005c23-6b06).

Zürcher 1991: 278, 297-298 [2013: 420, 442-443].

Zacchetti 2010.

T55n2145p0006a19: 轉法輪經一卷 (或云法輪轉經).

Zürcher 1991: 300 [2013: 444-445].

Nattier 2008: 46.

Nattier 2008: 68. 
személy fordította a müvet. ${ }^{28}$ Bárhogy is volt, abban egyetértés van a kutatók között, hogy egy nagyon korai szövegröl van szó. ${ }^{29}$

A legfontosabb kínai szövegek, amelyek valamilyen formában tartalmazzák a Tan kerekének megforgatásával kapcsolatos beszédet, a következők:

K1: T02n0109 - Fo shuo zhuan falun jing 佛說轉法輪經; ford. An Shigao (?) 安世高 (i. sz. 2. sz.).

K2: T04n0196p148b1-c16 - Zhongbenqi jing 中本起經 [Madhyama-ityukta Sutra]; ford.: Tanguo 曇果 és Kang Mengxiang 康孟詳 (2. sz.).

K3: T02n0125p0593b24-c10, T02n0125p0619a08-b19 - Zeng yi ahan jing 增壹阿含經 10, 14 [Ekottarikāgama]; ford.: Gautama Saṃhadeva (Qutan Sengjiatipo 睢昙僧伽提婆, 4. sz.), Mahāsānghika hagyomány. ${ }^{30}$

K4: T22n1421p104b23-105a2: Mishasai bu hexi wufen lü 彌沙塞部和䤈 五分律 [Mahīśāsakavinaya], ford.: Fotuoshi 佛陀什 és Zhu Daosheng 䇥道生 (4-5.sz.). ${ }^{31}$

K5: T22n1428p788a6-c7 - Sifen lü 四分律 [Dharmaguptaka Vinaya]; ford.: Buddhayaśas (Fotuoyeshe 佛陀耶舍) és Zhu Fonian 竺佛念 (5. sz.). ${ }^{32}$

K6: T01n0099(379) - Ahanjing 阿含經 15; ford.: Gunabhadra (求那咙陀羅, 5. sz.), Mūlasarvāstivāda hagyomány. ${ }^{33}$

K7: T03n0189p644a23-c27 - Guoqu xianzai yinguo jing 過去現在因果經 3., ford.: Gunabhadra (求那跋陀羅, 5. sz.).

K8: T23n1435p448b13-449a7 - Shi song lü 十誦律 60; ford.: Vimalākṣa (卑摩羅叉, 5. sz.), Sarvāstivāda vinaya. ${ }^{34}$

K9: T03n190p811a14-812c4 - Fo benxing ji jing 佛本行集經 [Abhinișkramana-sūtra] 34; ford.: Jñānagupta (Shenajueduo 闍那崛多 (6. sz.).

K10: T02n0110 - Fo shuo san zhuan falun jing 佛說三轉法輪經, ford.: Yijing 義淨 (7. sz.) [= Genben shuo yiqie youbu pinaye zashi 根本說一切有部

28 Nattier 2008: 176: “Associated texts (possibly produced by members of An Shigao's school)."

29 Zürcher 1991: 300 [2013: 444]: “Archaic translation of the Buddha's first sermon held at Benares”; Zacchetti 1997: 381: „Si tratta comunque di un testo arcaico, come mostrano stile e terminologia."

Anālayo 2013: 10-13.

Anālayo 2013: 17-19.

Anālayo 2013: 21-24.

Anālayo 2012: 14, 17-19.

Anālayo 2012: 15. 
毘奈耶雜事 19; ford.: Yijing 義淨, 7. sz., T24n1451p0292a29-0292c15, Mūlasarvāstivāda vinaya hagyomány. ${ }^{35}$ ]

K11: T24n1450p0127b24-00128b15 - Genben shuo yiqie youbu pinaye po seng shi 根本說一切有部毘奈耶破僧事 6; ford.: Yijing 義淨 (7. sz), Mūlasarvāstivāda vinaya hagyomány. ${ }^{36}$

K12: T24n1451p0406c1-5, 0407a06-0407a17 - Genben shuo yiqie youbu pinaye zashi 根本說一切有部毘奈耶雜事 39; ford.: Yijing 義淨 (7. sz.), Mūlasarvāstivāda vinaya hagyomány. ${ }^{37}$

K13: T26n1537p0479b25-480a15 - Apidamo fayun zulun 阿毘達磨法蘊 足論 6 [Abhidharmadharmaskandhapādaśāstra]; ford. Xuanzang 玄奘 (7. sz.), Sarvāstivāda hagyomány. ${ }^{38}$

K14: T03n0187p607b15-c26 - Fangguang dazhuangyan jing 方廣大莊嚴經

1. [Lalitasvistara] ford.: Divākara (Dipokeluo 地婆訶羅; 7. sz.).

K15: T03n0191p954a2-b3 - Fo shuo zhong xu mohe di jing 佛說眾許摩訶 帝經 7. [Mahāsammatarāja-sūtra]; ford.: Faxian 法賢 (10. sz.).

Akár An Shigao, akár a fordítói köréböl származó másik személy végezte a fordítás munkáját, az bizonyos, hogy a T109 - egyet leszámítva - az összes ránk maradt fordításhoz képest jóval korábbi. Ez természetesen nem jelenti azt, hogy hitelesebb is lenne a többihez képest, hiszen könnyen elképzelhetö, hogy a jelen fordítás alapjául szolgáló eredeti indiai szöveg későbbi, mint a későbbi kínai fordítások alapjául szolgáló indiai szövegek. A Fo shuo zhuan falun mindenesetre számos sajátossággal rendelkezik, amelyek nem jellemzők a többi fordításra.

Számos kínai változatot a téma egyik legkiválóbb ismerője, Anālayo már lefordított és elemzett, ugyanakkor néhányat, köztük éppen ezt a legkorábbra datált fordítást, tudatosan kihagyott kétrészes tanulmányából, ${ }^{39}$ mégpedig a következő indoklással:

„Nem veszem figyelembe a T 109 sajátos kínai fordítását, amely azzal kezdődik, hogy a Buddha ezer szerzetes társaságában tartózkodott (T II 503b6), akiknek mindegyike arhattá válik az elbeszélés végére (T II 503c14).

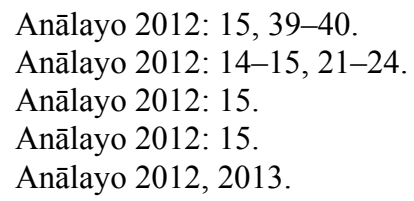


E jellemzők mellett, amelyek nem igazán egyeztethetők össze a Tan kerekének megforgatásáról szóló beszéd szokásos környezetével és befejezésével, a T 109 egyértelmúen a kései keletkezés jegyeit mutatja, amint erre Dessein (2007: 20f) már rámutatott. Így a beszéd egy tényleges kerék megjelenésének leírásával kezdődik, amely magától jelenik meg a levegőben a Buddha előtt, és amelynek ezután (Buddha) megparancsolja, hogy hagyja abba a forgást, mielőtt ö belekezdene a beszédébe (T II 503b7). Úgy tünik tehát, hogy a T 109 nem tartozik a Buddha öt korábbi (aszkéta)társához intézett első beszédének kanonikus változataihoz, bár könnyen elképzelhető, hogy e beszéd egyik változatainak bizonyos elemein alapul. A T 109-et Sastri (1938: 489-492) lefordította angolra. A tényleges kerék motívuma megtalálható a Lalitavistarában is (Lefman 1902: 415,10), ahol ez a kerék akkor jelenik meg, amikor a Buddha előkészül beszédére." ${ }^{40}$

Hasonló okokból ítélte Bart Dessein késeinek a T109-et egy korábbi tanulmányában:

„Végül pedig a »Fo shuo zhuan falun jing« (T.109) beszámolója párhuzamot mutat a vinaya irodalomban olvasható beszámolókkal, kivéve azt a tényt, hogy - amint ezt fentebb már említettem - a Buddha ezer szerzeteshez és istenek sokaságához intézi a beszédét. Ez utóbbi tényen kívül az utóbbi beszámolóra jellemző egyéb elemek is a kései keletkezésre utalnak: a Tan kereke a levegőben jelenik meg, és repülve kerül a Buddha szemei elé, aki azután kezével megragadja a kereket,

40 Anālayo 2012: 13. n.4: "I do not take into account the individual Chinese translation $\mathrm{T} 109$, a discourse that begins by indicating that the Buddha was in the company of a thousand monks, T II 503b6, all of whom at the conclusion of the discourse become arahants, T II 503c14. Besides these indications that do not square well with the standard setting and conclusion of the Discourse on Turning the Wheel of Dharma, T 109 shows clear signs of lateness, as already pointed out by Dessein 2007: 20f. Thus the discourse begins by describing an actual wheel appearing spontaneously in the air in front of the Buddha, which he then orders to stop turning before he begins to deliver his talk, T II 503b7. Thus T 109 does not seem to belong to the canonical versions of the Buddha's first discourse to his five former companions, although it may well be based on elements from a version of this discourse. T 109 has been translated into English by Sastri 1938: 489-492. The motif of an actual wheel is also found in the Lalitavistara, Lefman 1902: 415,10, where this wheel appears when the Buddha is about to deliver his first discourse." 
és megállítja a forgását, illetve hogy (beszéde) Kauṇ̣inyával egyidejüleg nyolcezer istent térít meg, és a beszéd hallgatóságát képező ezer szerzetes eléri az arhat szintet." ${ }^{41}$

Anālayo és B. Dessein szerint tehát a mindenki által legkorábbinak tartott kínai fordítás, illetve ennek feltételezett eredeti forrása olyan jellemzőket mutat, amelyek az eredeti szöveg kései mivolta mellett szólnak, habár Anālayo megjegyzi, nem elképzelhetetlen, hogy a szöveg tartalmaz eredeti, vagyis a korai fázishoz tartozó részeket. A T109-nek létezik két angol fordítása, az Anālayo által említett 1938-as, Sastri-féle fordítás mellett van egy Smith által készített 2001-es is. ${ }^{42}$ Általában elmondható, hogy Sastri fordítása jobb, de saját értelmezésem mindkettőhöz képest tartalmaz eltéréseket.

Jelen írásban a T109 szövegét alapvetően önmagában elemzem, néha a többi kínai fordítással összevetem (az egyszerüség kedvéért K2, K10 stb. hivatkozással), ugyanakkor a létező páli, szanszkrit és tibeti verziókat alapvetően nem használtam fel. E kínai fordítás pontos megértését nyilvánvaló módon nehezíti, hogy egy olyan időszakban készült, amikor a kínai buddhista terminológia még csak kialakulóban volt, így távolról sem volt egységes, széles körben elfogadott szókincse a fordításoknak.

\section{A T109 fordítása és értelmezése}

A következőkben az általam öt részre osztott beszéd egyes egységeinek kínai szövegét, magyar fordítását, illetve rövid értelmezését adom.

41 Dessein 2007: 20-21: "Finally, the account in the 'Fo shuo zhuan falun jing' (T.109) parallels the accounts we read in the vinaya literature, except for the fact that - as mentioned above - the Buddha addresses himself to one thousand bhikșus and a multitude of gods. Apart from this latter fact, also some other elements peculiar to the latter account point to its relative late date: the wheel of the doctrine appears in space and comes flying in before the Buddha's eyes, who then grasps the wheel with his hands and stops its turning, eight thousand gods are converted simultaneously with Kaundinya, and the one thousand monks he addressed, attain arhat-ship." 


\subsection{A bevezetö}

K1/a. 聞如是：一時，佛在波羅木奈國鹿野樹下坐。時有千比丘 、諸天神皆大會側塞空中。於是有自然法輪飛來, 當佛前轉。佛 以手撫輪曰：「止！往者吾從無數劫來為名色轉受苦無量, 今者 癡愛之意已止, 漏結之情已解, 諸根已定, 生死已斷, 不復轉於 五道也。」輪即止。 ${ }^{43}$ 於是, 佛告諸比丘:

„Ekként hallottam: Egyszer a Buddha Vārāṇasīban az Özliget [Mṛgadāva] (egyik) fája alatt ült. Ekkor ezer szerzetes és különféle égi lények gyülekeztek köréje úgy, hogy beborították az égboltot. Ekkor történt, hogy egy spontánul keletkezö törvénykerék odarepült, és a Buddha előtt forgott. Buddha a kezével megsimította a kereket, és így szólt: „Állj meg! A múltban megszámlálhatatlan kalpa óta a név-és-forma által továbbgördítve mérhetetlen szenvedéseken mentem keresztül, (de) most a tudatlanság- és ragaszkodástudat megállt, a szennyezett kötödések $^{44}$ szenvedélyei eloldódtak, a gyökerek ${ }^{45}$ megszilárdultak, az élet és halál (körforgása) elvágatott, nem születek újjá az öt út egyikén sem." A kerék erre megállt. Ezután a Buddha így szólt a szerzetesekhez:"

A beszéd helyszíne a Vārāṇasītól északkeletre, a modern Sārnāth-tól nem messze lévő Őzpark (sz. Mṛgadāva, p. Migadāya, k. Luyuan 鹿苑, Luyeyuan 鹿野園), máskor annak részeként említett Bölcsek ligete (sz. R R̦sipatana, p. Isipatana, k. Xianren yuan 仙人園). Hagyományosan itt mindössze öt aszkéta van jelen, a fenti kínai változat azonban nemcsak ezer szerzetesről, hanem égi lények sokaságáról is beszámol. Az öt aszkéta csoportként történő megnevezése ritkán hiányzik a többi szövegböl (K8: wu biqiu 五比丘, K10: wu bichu 五苾芻, K11: wu ren 五人, K12: wu biqiu 五比丘), és a K13 ugyan ,a szer-

43 Az idáig tartó rész rövidített formában, de szó szerinti idézetként beállítva megjelenik a 7. századi Fayuan zhulin 法苑珠林 (T53n2122p0370c18-21) címü enciklopédiában is, ld. később.

Loujie 漏結 = p. āsava, sz. sāsrava, āsrava.

45 Zhugen 諸根 = vonatkozhat az érzékszervi (szem [yan 眼], fül [er 耳], orr [bi 鼻], nyelv [she 舌] és test [shen 身] (sz. sarvêndriya) vagy szellemi (hit [xin 信], erőfeszítés [jin 進], tudatosság [nian 念], koncentráció [ding 定], bölcsesség [hui 慧]) képességekre, itt az utóbbira látszik utalni. 
zetesek sokaságáról” (bichu zhong 苾芻眾) beszél, ${ }^{46}$ de a szöveg végén itt is „öt szerzetes” (wu bichu 五苾媰) szerepel. ${ }^{47}$

Mint fent említettem, a beszédnél jelen lévő sokaság, valamint a keréknek a beszéd elején történő megjelenése arra késztette Anālayót, hogy a szöveg kései keletkezése mellett tegye le a voksát. ${ }^{48}$ André Bareau ugyanakkor éppen amellett érvel, hogy az eredeti verzióban szerepelhetett a nagyobb hallgatóság, amelyet csak később, éppen a beszédben általában szereplő, az aszkézist elítélő rész miatt kapcsoltak a Buddha élettörténetében szereplő öt aszkétához. ${ }^{49}$ Habár a kérdést aligha lehet eldönteni, mindenesetre Bareau értelmezése valamelyest magyarázatul szolgál arra, hogy az aszkézisnek a T109-ben feltủnően hiányzó elítélése (ld. jelen cikk 2. része) miképp függhet össze azzal a szintén ritka motívummal, hogy a Buddha nem az öt aszkétához intézi beszédét.

A következő egység a beszéd összes fennmaradt fordításához képest és az egész szövegen belül is a legfurcsább változatot tartalmazza. Egyrészt egyetlen más verzióban sem jelenik meg a magától forgó kerék megállitásának a motívuma, másrészt az itt leírtak első ránézésre mindenképpen ellentmondani látszanak a beszéd többi részének. Ez utóbbira vonatkozóan a beszéd egyértelmüen a Dharma kerekének megforgatásáról és nem megállításáról szól, másrészt a továbbiakban többször hangsúlyozódik, hogy egy olyan tanításról van szó, amely korábban még nem hangzott el, vagyis a tanítás újszerüsége többször is megjelenik, a bevezető részben pedig első ránézésre egy már forgó kerékkel találkozunk.

Mind Sastri, mind Anālayo utalnak arra, hogy ennek a résznek a Lalitavistarában van egy analógiája: ${ }^{50} \mathrm{itt}$ a beszéd elmondása előtt egy bodhisattva (Saha-cittôtpāda-dharma-cakra-pravartin) adományoz egy rendkívül gazdagon díszített kereket Buddhának, amely kerék a korábbi buddhák örökségét, azok tanításának a folytonosságát jelképezi. ${ }^{51}$ Véleményem szerint ez az analógia

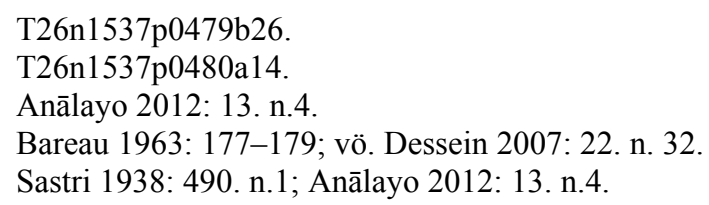

T26n1537p0479b26.

T26n1537p0480a14.

Anālayo 2012: 13. n.4.

Bareau 1963: 177-179; vö. Dessein 2007: 22. n. 32.

Sastri 1938: 490. n.1; Anālayo 2012: 13. n.4.

Dharmachakra Translation Committee 2013: 320-321: "Monks, at that point a bodhisattva, a great being, known as the One Who Turns the Wheel When the Intent Is Formed, offered a Dharma wheel to the Thus-Gone One. It was an exquisite wheel adorned with all kinds of jewels, gems, and various other embellishments. It had a hub, a rim, and a thousand spokes. It was adorned with flower garlands, lattices of gold, 
csak látszólagos: a T109-ben a kerék (az egyik értelmezés szerint legalábbis) egyrészt magától keletkezett (ziran 自然), ${ }^{52}$ semmiképpen sem egy istenség felajánlása (bár a csodás jelleg mindkét esetben megvan), másrészt a T109-ben semmi nyomát nem látjuk a Lalitavistarában rendkívül hangsúlyos díszítettségének, ahogy semmilyen utalás nem történik arra sem, hogy ez a korábbi buddhák láncolatához való kapcsolódást jelentené. Éppen ellenkezőleg, itt a Buddha megállítja a kereket, majd az élet és halál körforgásából történő saját megszabadulásáról beszél. Ez természetesen nem jelenti azt, hogy a két részlet ne függhetne valamilyen módon össze, feltehetően a Lalitavistara barokkos elbeszélése egy olyan jellegü szövegből indulhatott ki, mint a T109. ${ }^{53}$ Ha tehát a Lalitavistarában szereplö analógia az egyetlen, akkor a T109-ben egy teljesen egyedi motívummal van dolgunk. ${ }^{54}$

Véleményem szerint egy lépéssel közelebb kerülhetünk a megoldáshoz, ha ezt az elsőként megjelenő kereket másként értelmezzük, ugyanis a kerék megállítása után álló mondatok arra utalnak, hogy itt valójában nem a Dharmakerékről (falun 法輪), hanem a létesülés vagy az újjászületések kerekéről (shengsi lun 生死輪, youlun 有輪, kulun 苦輪, yelun 業輪) van szó, ebben az értelemben tehát a létesülésekben történő továbbforgás (lunhui 輪廻, lunzhuan 輪轉) megállításáról szól a bevezető előhang. A szöveg első ránézésre ugyanakkor Dharma-kereket említ (falun), mintha a két kerék képe egy-

tassels with bells, and the motifs of an elephant in rut, a filled vase, and a swastika. The wheel was adorned with various marks of auspiciousness, beautifully wrapped in divine fabrics and dyed in different colors. It was strewn with flowers of the heavens, adorned with fragrant garlands, and rubbed with perfumed ointments. In this way it was a wheel as beautiful as can be. It came about through the power of previous aspirations made as the Bodhisattva had trained. It was truly a suitable offering to the Thus-Gone One. [F.199.b] Since all the previous thus-gone ones in succession had accepted this wheel, it possessed the unbroken blessings of all the buddhas. In fact this wheel had previously been turned by all former thus-gone ones, worthy ones, perfect buddhas, and therefore it was now offered to the Thus-Gone One for turning."

52 Zacchetti (1997: 381-382. n. 4) ezt a tulajdonságot a más szútrákban elhangzó beszédek elején található csodás elemek közé sorolja.

53 Ruzsa Ferenc javaslata szerint a 自然法 szanszkrit eredetije a saha-ja-dharma lehetett, amelynek szinonimája (a sahôtpāda) éppen a Lalitavistara bodhisattvájának nevében (Saha-cittôtpāda-dharma-cakra-pravartin) köszön vissza.

Vö. Zürcher 1991: 300 [2013: 444]: “Archaic translation of the Buddha's first sermon held at Benares, with an introductory passage that does not appear in any other known version." 
beíródna, ${ }^{55}$ és a Dharma-kerék által később kifejtendő igazság felszámolná a létkerék kényszerítő erejét.

Valószínűbbnek tünik tehát, hogy Sastrinak igaza van, amennyiben a kissé európai ízü fordítását ("the Wheel of Law of Nature") közelebbröl megvizsgáljuk, ${ }^{56}$ és megállapítjuk, hogy a ziran 自然 ('spontán, magától lévő, magától keletkezett, természetes') nem a falun 法輪 (Dharma-kerék) egészének jelzője ${ }^{57}$ hanem talán csak a 'törvény' jelentésü $f a$ 法 szóhoz tartozik. Ebben az esetben tehát a természetre jellemzö törvény (élet és halál körforgása, újjászületések) kerekének megállításáról van szó. Annak ellenére, hogy a ziran $f a$ 自然法 nem nevezhető általános terminológiának, ugyanakkor a fordítás korai mivolta, a terminológia kialakulatlansága kellőképpen indokolhatja, a kontextus pedig egyenesen igényli ezt az értelmezést. Mindezt egyértelmüen megerősíti a T109-ben a szöveg kontextusa, továbbá az a tény, hogy nemigen lehet szövegromlásról szó, mivel a 668-ban összeállított Fayuan zhulin 法苑 珠林 11. fejezete összefoglalva idézi éppen ezt a részt:

„Továbbá a Dharma-kerék megforgatása szútra ezt mondja: »A Buddha az Özliget egyik fája alatt tartózkodott, amikor a levegőben odarepült egy magától (keletkező) Dharma-kerék [v. 'A magától keletkezés törvényének kereke'], és a Buddha előtt forgott. A Buddha a kezével végigsimítva megállította: 'Én kezdettelen idők óta a név-és-forma által forgok a keréken, most a ragaszkodás-tudat véget ér, nem forgok többé az újjászületések árjával.' A kerék erre megállt. «"

\section{又轉法輪經云：佛在鹿野樹下時，空中有自然法輪飛來，當佛前 而轉。佛以手撫之: 「止！吾無始來為名色轉輪, 今愛意盡, 不 復流轉。」輪即便住。(T53n2122p0370c18-21)}

A Tang-kori szöveg éppen azáltal hiteles tanúja a T109 itt vizsgált passzusának, hogy nem teljes mértékben szó szerint, hanem lényegileg idézi; a két szöveg terminológiája különbözik ugyan, de mindkettő egyértelmüen arra utal, hogy a „természet-törvény kereke” a létkerékkel azonos:

55 Szegedi Mónika gondolata.

56 Sastri 1938: 489.

57 Fontos megjegyezni, hogy a ziran itt nem lehet határozó (,,magától [csodálatos módon] ott termett egy Dharma-kerék”), mert az you ziran 有自然 helyett ziran you 自然有 lenne, ami gyakran elő is fordul a buddhista szövegekben, például: T01n0023p0282a01, T02n0125p0737a06, T04n0200p0236b25. 
1. T2122: „kezdettelen időktől fogva” (wushi lai 無始來) - T109: „,megszámlálhatatlan kalpák óta" (cong wushu jie lai 從無數劫來);

2. T2122: „most a ragaszkodástudat véget ér” (jin aiyi jin 今愛意盡) - T109: „most a tudatlanság- és ragaszkodástudat megállt” (jinzhe chi'ai zhi yi 今者 癡愛之意已止);

3. T2122: „nem forgok többé az újjászületések árjával” (bu fu liuzhuan 不復 流轉) - T109: ,az élet és halál (körforgása) elvágatott, nem születek újjá az öt út egyikében sem" (shengsi yi duan, bu fu zhuan yu wudao ye 生死 已斷, 不復轉於五道也).

Mindez tehát azt jelenti, hogy a szútra többi verziójához képest ugyan valóban egyedi az itt felvázolt kép, de egyrészt semmiképpen sem érthetetlen vagy ellentmondásos úgy, amint első pillantásra tünik. Ez az értelmezés nem pusztán az utána következő résszel és a szutta egészével kompatibilis, hanem különleges módon ellenpontozza a szutta egészének központi motívumát, a létesülés mozgásaival szembe haladó buddhista igazság (dhamma) kerekének a megforgatását. Így a szutta elején a Buddha megállítja ,a természetre jellemző törvény kerekét", amely egyben e létesülések körforgásából való kiszabadulását és az e feletti hatalmát mutatja be, hogy azután nem sokkal később elindítsa a buddhista igazság kerekét, amely feltehetően éppen az ellenkező irányba forog. Ebben az értelmezésben tehát a szöveg mintha azt sugallná, hogy a buddhista Dharma-kerék elindítása nem más, mint a létkerék megállítása és annak ellenkező irányba történő forgatása.

\subsection{A két elkerülendő véglet}

K1/b. 「世間有二事墮邊行，行道弟子、捨家者終身不當與從 事。何等二? 一為念在貪欲, 無清淨志, 二為猗著身愛, 不能 精進。是故退邊行, 不得值佛道德具人。若此比丘不念貪欲著 身愛行, 可得受中, 如來最正覺得眼得慧, 從兩邊度自致泥洹。

„A világon két olyan cselekedet van, amely szélsőségekre juttat, és a gyakorló tanítványoknak, a családjukat elhagyóknak életük végéig nem szabad ezeket követniük. Melyik ez a kettő? Az egyik (az, ha valakiben) 
a mohó vággyal teli gondolatai miatt megszünik a tisztaságra való törekvés. A másik (az, ha valaki) a testi szenvedélyétől való függése miatt képtelenné válik arra, hogy erőfeszítést tegyen a (szellemi) elörehaladásában. Ezért, ha (valaki) e szélső utakra tér, annak nem lesz alkalma, hogy egy buddhával vagy egy erényes, tökéletes emberrel találkozzon. ${ }^{58}$ Mivel ez így van, ezért, szerzetesek, (én) a mohóságra és a vágyakra nem gondoltam, a testi vágyakhoz nem ragaszkodva cselekedtem, elértem a középutat, és tathāgataként a legtökéletesebb megvilágosodás révén elnyertem a belátást és a bölcsességet, és a két szélsőség között eljutottam a nirvánára."59

Ez a rész az itt vizsgált szutta olyan kínai verziója, amely a buddhizmus egyik leghíresebb tételének, az élvezetekben való elmerülés és a túlzásba vitt aszkézis kettősségének ${ }^{60}$ elkerülését egyáltalán nem egyértelmüen fogalmazza meg.

Az első szélsőség explicit módon a mohó vágyakban (tanyu 貪欲) való gondolati elmerülést és a tisztátalan szándékokat említi. Ez ugyan jellemzője lehet a szélsőség egyik pontjaként általában említett érzéki örömökben való tobzódásnak, de inkább csak egy gondolati, érzelmi szinten. A T109-ben másodikként említett szélsőségben a yizhuo 猗著 valamire való 'támaszkodást', valamitől való 'függést' (sz. niśrāya, niśrita) jelent, ${ }^{61}$ az utána álló

58 Ezt az értelmezést a következő párhuzamos szövegre alapozom: „Ebben a két dologban ha visszaestek a szélsőséges cselekvésre, az életben nem találkoztok egy buddhával, és messze elkerülitek az igaz utat" (T04n0196p0148b24-25: 是二事, 還墮邊行, 生不值佛, 違遠真道。).

59 A nirvāna szónak itt egy korai fonetikus átírása szerepel (nihuan 泥洹) a később bevett niepan 涅槃 helyett.

60 Mindkét szélsőséget általában úgy szokás felfogni, mint amit a történeti Buddha (hagiográfiája alapján) maga is átélt: az előbbi a palotában eltöltött évekre vonatkozik, míg az utóbbi a megvilágosodása előtti, hat évig tartó aszketikus gyakorlataira. Létezik természetesen egyéb értelmezés is: Vekerdi József (1989: 182. n. 34) szerint az önkínzás elsősorban a Buddha korában népszerü dzsainizmusra utal, míg Körtvélyesi Tibor (2018: 190) disszertációjában az első azonosítást kérdőjelezi meg: „A Vinaya legalábbis azt sugallja, hogy a Benáreszi beszédben kifejtett két véglet közül az aszketikus az Ötök Csoportjának társaságához szól, a másik véglet pedig egy olyan társasághoz, akik - az erös szexuális utalások alapján - valamilyen rituális-szexuális praxist müvelnek, noha ennek konkrét tartalma nem ismert. Azt sosem fogjuk megtudni, hogy a Buddha a megvilágosodása elötti időből valóban közelről ismerte-e ezt a társaságot, vagy egyáltalán létezett-e ilyen társaság, de a Vinaya és a kommentárhagyomány alapján mindez, ha hipotézisként is, felvethető." http://www.buddhism-dict.net/cgi-bin/xpr-ddb.pl?q=猗著 (utoljára megtekintve: 2019.07.06). 
shen 'ai 身愛 pedig ugyan nem bevett kifejezés, de első ránézésre nem jelenthet nagyon mást, mint a 'testi vágyakat', 'testi szerelmet', 'egyéni ragaszkodást', együtt tehát egy olyan ember képét rajzolja elénk, aki teljes mértékben a testi vágyaitól függ, és amelyek már olyan mértékben a hatalmukba kerítették, hogy ezért nem képes a megfelelő irányba erőfeszítést (jingjin 精進; vīrya) tenni. Ez utóbbi tehát közelebb áll az itt szokásosan említendő érzéki élvezetekhez, és rejtélyesnek tünik, hogy a két szélsőség közül hova tünt a szélsőséges önmegtartóztatás, az aszkézis.

E dilemmára Smith enyhe „understatement”-tel így reagál: “The difference and how there are two extremes here, is not very clear." ${ }^{2}$ Zacchetti megjegyzi, hogy a kínai változat a jelenlegi formájában aligha felel meg két szélsőség ellentétének. ${ }^{63}$ A mondathoz füzött lábjegyzetében Sastri hasonló módon csodálkozását fejezi ki, hogy a két szélsőséges viselkedés a szöveg tükrében alig különbözik egymástól ("which hardly differs in substance from the first Extreme"), ugyanakkor felvet egy ötletet, amelyet azonban azonnal el is vet. ${ }^{64}$ Az ötlet az ài 愛 írásjegy speciális értelmezésén alapul: miközben fordításában mind Sastri, mind Smith a bevett jelentését használja ('ragaszkodás, szeretet'), addig e lábjegyzetben Sastri arra utal, hogy elméletileg elképzelhető lenne az ezzel ellentétes 'gyülölet' jelentést alkalmazni, amely esetben a shēn'ài 身愛 kifejezés nem a testi vágyakat, hanem a 'test gyülöletét', kicsit továbbgondolva pedig az aszkézist jelentené, vagyis ebben az esetben a testi aszkézisre való túlzott támaszkodás okozná az elörelépésre való képtelenséget. Magam részéről nem találtam bizonyítékot arra, hogy az shēn'ài valóban jelenthetné a 'test gyülöletét', és ezt két okból sem tartom valószínünek: egyrészt ezt a fordító könnyedén kifejezhette volna más, egyértelműbb igékkel (például wù 惡), másrészt ebben az esetben a wushen 惡身 sorrend lenne a megfelelö.

Zacchetti abból indul ki, hogy a páli alak (attakilamathânuyogo, akárcsak a szanszkrit alak, ātmakilamathânuyogo vagy ātmakāyaklamathânuyogo) az egyén kimerítésére, kifárasztására utal, amelyben a shēn 身 megfeleltethető az egyénnek ${ }^{65}$ (p. atta, sz. ātman, àtmakāya, ez utóbbi jobb analógia az 'individuum', illetve 'test' jelentésü shenhez), így a probléma az ài 愛 szóval

62 Smith 2001: 24. n.58.

63 Zacchetti 1997: 383: „Non c'è dubbio che, così come si presenta, questo passo manca proprio di quell'opposizione tra i due estremi che è testimoniata dalle altre versioni."

64 Sastri 1938: 490. n.1.

65 Zacchetti 1997: 384. 
van, amelyet Zacchetti a yōu 憂 írásjegyre ('bánatos, melankolikus, csüggedt') emendál, és bemutatja, hogy a két írásjegy összetévesztése általánosan megfigyelhető. ${ }^{66}$ Első ránézésre ez kiváló ötletnek tünik, ami megoldani látszik a problémát, ugyanakkor két megfontolást érdemes figyelembe venni. Egyrészt az így emendált szöveg (猗著身憂) nem fordul elő egyetlen kínai buddhista szövegben sem. Másrészt létezik egy szintén koraiként számontartott szöveg, a Keleti Han-korban (i. sz. 25-220) élő Tanguo 曇果 és Kang Mengxiang 康孟詳 által közösen fordított Zhong benqi jing 中本起經 (Madyama-ityukta sūtra, fent K2), amelyben a T109-hez hasonlít abban, hogy benne nem a bevett szélsőségeket említő megfogalmazás jelenik meg:

„Buddha így szólt a szerzetesekhez: kétfajta olyan viselkedés van, amely szélsőségekre juttat: »az első az, ha valaki érzéki vágyakra gondol (mindig), és nincsenek tiszta szándékai; a második pedig, ha a vágyakra támaszkodik, és a mohósághoz kötődik, és így már nem képes tisztán cselekedni.«"

佛告比丘：「行有二事, 為墮邊際：一者念在色欲, 無清淨志 ; 二者猗愛著貪, 不能清志行。67

Ez az idézet, amelyben számos kifejezésbeli egybeesés (墮邊, 念在, 無清 淨志, 猗著) található, a T109-vel lényegében azonos módon fogalmazza meg a két szélsőséget, ráadásul itt lehetőségünk sincs arra, hogy a test fárasztásaként (vagy Sastri értelmezésére visszautalva 'gyülöleteként') értelmezzük a passzus megfelelő részét (mivel a test, shen 身 szó egyáltalán nem is szerepel benne), továbbá ebben az esetben Zacchetti emendatióját más szempontból sem lehetséges érvényesíteni, mivel a yi 猗 és a $z h u o$ 著 írásjegyekhez hasonlóan az ai 愛 és a tan 貪 állnak párhuzamban, és az egyértelmüen 'mohóságot' és 'vágyat' jelentő tan 貪 semmilyen módon nem lehet szinonimája a you-ra ('szomorúság, letörtség') emendált ai-nak ('vágy, ragaszkodás'), pedig az eredeti változat nyilvánvaló teljesen megfelel a párhuzamos szerkesztés szabályainak, tehát ahogy a 猗 és a 著 párhuzamosak, ugyanígy kell felfognunk az ai-t 愛 és a tan-t 貪 is.

A T109 és a T196 alapján tehát nem az élvhajhászás és az aszkézis bevett kettősségének a képe bontakozik ki elöttünk, hanem a testi vágyakhoz és élvezetekhez történő gondolati-érzelmi, illetve cselekvés szintjén megjelenő

66 Zacchetti 1997: 385-388.

67 T04n0196p0148b22-24. 
kötődés, illetve ezek következménye, a tisztátalan szándék és az erőfeszítésekre való képtelenség. ${ }^{68}$

Ebben a tekintetben a T109 megfogalmazása tehát nem teljesen egyedi, de mindenképpen ritka. Habár felmerülhet annak az elméleti lehetősége, hogy itt egy olyan irányzat szövegváltozatáról van szó, amely nagy becsben tartotta az aszkézist (vö. p. dhutanga, k. tóutuó 頭陀), így nem kívánta ugyanazon a szinten tárgyalni, mint a nyilvánvalóan elítélendő érzéki kicsapongást, de egy ilyen irányzati hátteret aligha lehetne bizonyítani.

\subsection{A négy nemes igazság}

K1/c. 何謂受中? 謂受八直之道:一曰正見, 二曰正思, 三曰正 言, 四曰正行, 五曰正命, 六曰正治, 七曰正志, 八曰正定。 若諸比丘本末聞道, 當已知甚苦為真諦, 已一心受眼, 受禪思, 受慧見, 覺所念, 令意解。

當知甚苦習盡為真諦, 已受眼觀禪思慧見, 覺所念令意解, 如 是盡真諦。

何謂為苦? 謂生老苦、病苦, 憂、悲、惱苦, 怨憎會苦, 所愛 別苦, 求不得苦, 要從五陰受盛為苦。

何謂苦習? 謂從愛故而令復有樂性, 不離在在貪熹, 欲愛、色 愛、不色之愛, 是習為苦。

何謂苦盡? 謂覺從愛復有所樂, 婬念不受, 不念無餘無媱, 捨 之無復禪, 如是為習盡。

何謂苦習盡欲受道？謂受行八直道，正見、正思、正言、正行、 正命、正治、正志、正定, 是為苦習盡受道真諦也。

„Mit nevezünk középső útnak? A nyolc egyenes ösvényt: az első a helyes nézet, a második a helyes gondolkodás [sī 思], a harmadik a helyes beszéd, a negyedik a helyes cselekvés, az ötödik a helyes élet, a hatodik a helyes 'irányítás' [erőfeszítés], a hetedik a helyes szándék, a nyolcadik a helyes elmélyedés.

Szerzetesek, én eredendően nem hallottam az igazságról, (de) amikor már megismertem, hogy a szenvedés a végső igazság, akkor teljes tuda-

68 Ruzsa Ferenc felhívta a figyelmemet, hogy ez a kettősség megfelel a megvilágosodása előtt álló Buddha elképzeléseinek (például az MN 36 három, összefüggő példázata a különböző típusú fadarabok tüzfúró pálcával történő meggyújtásáról). 
tom elnyerte a látást, megkaptam a kontemplatív gondolkodást, elnyertem a bölcs belátást, akkor felébredtem gondolataimból, és (ennek) révén elmém megszabadult.

Amikor megismertem, hogy a szenvedés felhalmozódásának [okának $]^{69}$ megszüntetése a végső igazság, akkor elnyertem a látást, a kontemplációt, az elmélkedést és a gondolkodást, a bölcs belátást, akkor ráébredtem az elmélkedés tárgyára, (ennek) révén elmém megszabadult. Ez (a szenvedés) megszűnésének végső igazsága.

Mit nevezünk szenvedésnek? A születéssel és halállal járó szenvedéseket nevezzük annak, a betegség szenvedését, a szomorúság, fájdalom és keserv szenvedését, a gyülölttel való találkozás szenvedését, a szeretettől való elválás szenvedését, a vágyott el nem érésének szenvedését. Összefoglalva tehát: az öt skandha teljes (müködéséből) szenvedés származik.

Mit nevezünk a szenvedés felhalmozódása [okának]? Ezt nevezzük: a vágyakból származóan újra (és újra) megszületik az élvezettermészet, így nem szabadul meg a mindenütt ${ }^{70}$ előforduló mohóságtól és örömtől, a kívánságoktól, az érzéki és nem érzéki jellegü vágyaktól. Ez a szenvedés felhalmozódása [oka].

Mit nevezünk a szenvedés megszüntetésének? Ha felébredünk azokból a vágyakból, amelyekből az újralétesülésre vonatkozó élvezettermészet (lesz), ha az érzéki gondolatokat nem fogadjuk el, ha nem gondolunk rájuk, és maradék nélkül ${ }^{71}$ megszünik az érzékiség, ha elvetjük azokat és már nem gondolunk rájuk többé, ezt nevezzünk a szenvedés megszünésének.

Mit nevezünk a szenvedés megszüntetéséhez vezető út elnyerésének? A nyolc egyenes utat nevezzük annak: a helyes nézetet, a helyes gondolkodást, a helyes beszédet, a helyes cselekvést, a helyes életet,

${ }^{69}$ A $x i$ 習 írásjegy itt az egyébként ebben az összetételben gyakrabban használatos $j i$ 集 ('felhalmozódik, összegyülekezik') szó megfelelőjeként (http://www.buddhismdict.net/cgi-bin/xpr-ddb.pl?q=習, utoljára megtekintve: 2019.07.06), és a szanszkrit samudaya értelmében használják, ami a ji 集 szóhoz hasonlóan egyrészt jelent összetalálkozást, felhalmozódást ('coming together, union, junction, combination, collection, assemblage, multitude, aggregation, aggregate'), másrészt viszont valaminek a létrehozó okát ('a producing cause') is jelölheti (Monier-Williams 1899: 1167b). A zaizai 在在 formailag is a páli és szanszkrit tatra-tatra megfelelője.

71 A wúyú 無餘 ('maradék nélküli, teljes') a páli asesa és a szanszkrit aśeșa megfelelője. 
a helyes 'irányítást' [erőfeszítést], a helyes szándékot, a helyes elmélyedés. Ez a szenvedés megszüntetéséhez vezető út elnyerésének végső igazsága."

Az előző részben a középső útnak (shou zhong 受中) nem a szokásosként megnevezett két véglet elkerülését nevezte a szöveg, itt az ugyanerre vonatkozó kérdésre a 'nyolc egyenes út elnyerését' (shou ba zhi zhi dao 受八直 之道) ${ }^{72}$ illetve ennek tagjait adja meg, amely egyben a válasz a szenvedés megszüntetéséhez vezető úttal kapcsolatban is.

A T109-ben mindkét kifejezésben szerepel a meglehetösen különös shou 受 ('megkap, elfogad, megtapasztal') kifejezés. A középső út (p. majjhimā patipadā, sz. madhyamā pratipad) a K1-ben tehát 受中, a K12-ben 處中法. Annak ellenére, hogy a szanszkrit kifejezésben szereplő pratipad jelentése itt 'the path to be walked, the right path', ${ }^{73}$ így a pontos megfelelöje az egyébként általánosan erre használt zhongdao 中道 ('középső út'), a T109 fordítója láthatólag a pratipad szóban az 'obtain, receive' jelentést látta, ${ }^{74}$ együttesen tehát a közép (zhong 中) elfogadását, esetleg megtapasztalását (shou 受).

Annak magyarázatát, hogy miként függ össze a szélsőségek elkerülése ezzel a nyolc elemmel, az elnevezés szintjén legalábbis minden bizonnyal a minden elemnél megjelenő 'megfelelö, helyes' (p. sammā, sz. samyak) kitétel nyújtja, vagyis hogy például a gondolatokat, a szavakat vagy a cselekedeteket lehet szélsőségesen túlzásba vinni (például feleslegesen sokat beszélni vagy némasági fogadalmat tenni), de a megfelelő út e két szélsőség között fekszik. Az már külön kérdés, hogy éppen a T109 (továbbá a T196), amint ezt láttuk, csak az egyik végletet bontja ki két szinten.

Annak alapján, hogy a nemes nyolcrétü ösvény a végletek elkerülésével együtt szerepel, B. Dessein (Bareau-ra és Bronkhorstra hivatkozva) valószínünek tartja, hogy a negyedik nemes igazság lett elsőként kifejtve, illetve hogy a négy nemes igazság mint egység egy későbbi módosítás eredménye (Frauwallner, Schmithausen, Vetter, Bronkhorst műveire való hivatkozással). ${ }^{75}$

A páli (akárcsak a szanszkrit Lalitavistara, Sanghabhedavastu, Mahāvastu) ugyanígy kétszer sorolja fel a nyolcrétủ nemes ösvényt, amelynek tagjai

72 A nyolctagú ösvény néhány egyéb, többször előforduló kínai elnevezése (SoothillHodous 1977: 37 alapján): $b a$ zheng dao 八正道 (ba zheng dao fen 八正道分), $b a$ sheng dao zhi 八聖道支, ba daohang 八道行, ba zhi hang 八直行, ba zhi dao 八直道.

74 Monier-Williams 1899: 667a.

75 Dessein 2007: 21, n .28 és n. 29. 
a kínai fordításokban alapvetően vagy teljes mértékben azonosak (1. 見, 5 . 命, 8. 定), vagy minimálisan térnek el (3. 正, 語; 4. 行, 業), és csak az esetek kis részében találunk ennél jelentősebb különbséget, a T109-ben két esetben: a szokásos 'helyes erőfeszítés' (zheng jingjin 正精進) helyett 'helyes irányítás, kézben tartás' (zheng zhi 正治) ${ }^{76}$ a bevett 'helyes gondolkodás' (zheng nian 正念) helyett pedig a 'helyes szándék' (zheng zhi 正志) jelenik meg. Mindkét eltérés megtalálható a T196-ban is.

\section{A NEMES NYOLCRÉTÜ ÖSVÉNY}

\begin{tabular}{|c|c|c|c|c|c|}
\hline T109 & T196 & T1451 & T398 & Páli & Szanszkrit \\
\hline 1. 正見 & 正見 & 正見 & 正見 & sammā-dițhi & samyag-dṛștii \\
\hline 2. 正思 & 正利 & 正思惟 & 正念 & $\begin{array}{c}\text { sammā- } \\
\text { sañkappo }\end{array}$ & $\begin{array}{c}\text { samyak- } \\
\text { sam̄kalpa }\end{array}$ \\
\hline 3. 正言 & 正言 & 正語 & 正言 & sammā-vācā & samyag-vāc \\
\hline 4. 正行 & 正行 & 正業 & 正業 & $\begin{array}{c}\text { sammā- } \\
\text { kammanto }\end{array}$ & $\begin{array}{c}\text { samyak- } \\
\text { karmānta }\end{array}$ \\
\hline 5. 正命 & 正命 & 正命 & 正活 & sammā-ājīvo & $\begin{array}{c}\text { samnyag- } \\
\overline{a j j i ̄ v a ~}\end{array}$ \\
\hline 6. 正治 & 正治 & 正精進 & 正便 & $\begin{array}{c}\text { sammā- } \\
\text { vāyāmo }\end{array}$ & $\begin{array}{c}\text { samyag- } \\
\text { vyāyāma }\end{array}$ \\
\hline 7. 正志 & 正志 & 正念 & 正意 & sammā-sati & samyak-smṛti \\
\hline 8. 正定 & 正定 & 正定 & 正定 & $\begin{array}{c}\text { sammā- } \\
\text { samādhi }\end{array}$ & $\begin{array}{c}\text { samyak- } \\
\text { samādhi }\end{array}$ \\
\hline
\end{tabular}

A fenti részletben a szenvedés definíciójánál szerepel, hogy a különféle szenvedéstípusokról lényegében (yao 要) elmondható, hogy az 'öt skandha' (wuyin 五陰, gyakrabban wuyun 五蘊) müködéséből származik a szenvedés. ${ }^{77} \mathrm{Ez}$ az utóbbi kitétel azért tünik érdekesnek, mert a páli kandha és a szanszkrit skandha egészen pontosan a kínai változatnak megfelelö helyen elöfordul a páli Dhammacakkappavattana-suttában (SN 56.11), illetve mindhárom szanszkrit szövegben (itt a Mahāvastut idézve): ${ }^{78}$ a szenvedés nemes igazsága

76 A T13n0398p0434a28-ban az egyébként ötödikként szereplő 正活 helyett szerepel bizonyos helyeken tévesen (tehát az írásjegyek hasonlósága miatt) a 正治.

77 T02n0109p0503b24-25: 要從五陰受盛為苦。Alapvetően (從 helyett 因) ugyanez a mondat megtalálható a T196-ben (T04n0196p0148c02-3) is: 要因五陰受盛為苦.

78 Mindkét szöveg esetében a Ruzsa Ferenc által összeállított szöveget (ed. Gnoli) vettem figyelembe. 
(dukkham ariya-saccam; duḥkham ārya-satyam) kifejtésénél a születés (p. jāti, sz. jāti, k. sheng 生), az öregség (p. jarā, sz. jarā, k. lao 老), a betegség (p. byādhi, sz. vyādhi, k. bing 病) és a halál (maraṇa, maraṇạ̣, ez a kínaiban itt nem szerepel) után az összetettebb kifejezésü szenvedésformák (p. appiyehi sampayogo, sz. apriya-samprayogam, k. yuanzeng hui 怨憎會; p. piyehi vippayogo, sz. priya-viprayogam, k. suo ai bie 所愛別; p. yam p'iccham na labhati, sz. yam pîcchanto paryeșanto na labhati, k. qiu bu de 求不得) következnek, majd utána szerepel a számunkra releváns mondat: „Összefoglalva: a sajátítás (ragaszkodás) öt halmaza szenvedés” (p. saṃkhittena pañc'upādānakkhandhā dukkhā, sz. saṃkșiptena pañcôpādāna-skandhā duhkhāa).

Mivel a T109-es (és a T196-os) kínai változat viszonylag pontosan megfeleltethető a fenti páli és szanszkrit szövegek megfelelő részeinek (bár nyilvánvalóan nem közvetlen fordítása ezeknek), így feltételezhetjük, hogy a wuyin shousheng 五陰受盛 a pañc'upādāna-kkhandhā, illetve a pañca upādānaskandhạh megfelelője. Ez azért fontos, mert a fenti kifejezés a teljes kínai buddhista kánonban csak a T109-ben és a T196-ban fordul elő. Ha hozzátesszük, hogy néhány hasonló kínai kifejezés (wu sheng yin ku 五盛陰苦, wu yin sheng $k u$ 五陰盛苦) azokat a szenvedéseket ( $k u$ 苦) jelöli, amelyek a szkandhák (wuyin 五陰) teljes körü (sheng 盛) müködéséböl származnak, ${ }^{79}$ akkor egyértelmünek tünik, hogy a T109-ben is abban az értelemben szerepel, amelyre a kínai buddhista hagyomány egyébként a wu qu yun 五取蘊 kifejezést ('az öt kisajátító összetevő', 'az öt ragaszkodást képző halmaz') használja. ${ }^{80}$

\subsection{A tizenkét 'menet'}

K1/d. 「又是, 比丘！苦為真諦, 苦由習為真諦, 苦習盡為真 諦, 苦習盡欲受道為真諦。

若本在昔未聞是法者, 當受眼觀禪行, 受慧見, 受覺念, 令意 得解。

79 Soothill-Hodous 1977: 122: "The mental and physical sufferings arising from the full-orbed activities of the skandhas."

80

"Five constituents subject to appropriation; the five aggregates as objects of impure attachment; contaminated five aggregates" (五取蘊, Digital Dictionary of Buddhism, online elérhetőség: http://www.buddhism-dict.net/cgi-bin/xpr-ddb.pl?q=五取䒸, utoljára megtekintve: 2019.07.06). 
若令在斯未聞是四諦法者, 當受道眼, 受禪思, 受慧覺, 令意 行解。

若諸在彼不得聞是四諦法者, 亦當受眼、受禪、受慧、受覺, 令意得解。

是為四諦三轉合十二事, 知而未淨者吾不與也, 一切世間諸天 、人民，若梵、若魔、沙門、梵志。自知證已，受行戒、定、 慧、解、度知見成, 是為四極。是生後不復有, 長離世間, 無 復憂患。」

„Továbbá, szerzetesek, a szenvedés a végső igazság, a szenvedés eredete a végső igazság, a szenvedés felhalmozódásának [okának] megszüntetése a végső igazság, a szenvedés felhalmozódása [oka] megszüntetéséhez vezető út elnyerése a végső igazság.

Mivel egykoron régen (senkitől) nem hallottam még ezt a Tanítást, (nekem magamnak) kellett elnyernem a (helyes) látást, elérnem a kontempláció és elmélkedés módszereit, megkapnom a bölcs belátást, elnyernem a felébredéstudatosságot, hogy elmém ezáltal megszabaduljon.

Mivel ebben (a világban) nem hallottam e négy igazság tanítását, (nekem magamnak) kellett elnyernem az igazságszemet, elnyernem a kontemplatív gondolkodást, elérnem a bölcsességfelébredést, hogy (ezek) révén elmém felszabaduljon.

Mivel a jövőben sem lesz alkalmam hallani e négy igazság tanítását, (nekem magamnak) kellett elnyernem a (helyes) látást, elérnem a kontemplációt, elnyernem a bölcsességet, elnyernem a felébredést, hogy (ezek) révén elmém megszabaduljon.

Ez a négy igazság háromszor megforgatva összesen a 12 'menet'.

Amikor megismertem, de még nem tisztultam meg, nem osztottam meg (ezt a tudást) a különböző világokban lévő istenségekkel (deva), emberekkel, brahmākkal vagy mārákkal, szerzetesekkel vagy brahmacārinokkal. ${ }^{81}$ Miután magamtól megismertem és megtapasztaltam, gyakoroltam a viselkedésre vonatkozó elöírásokat, a meditációt és a bölcses-

81 A fanzhi 梵志 a brāhmaṇa kínai megfelelője (a kínai értelmezésben a fan 梵 a brahm-, a zhi 志 a manas megfelelöje), első elöfordulása éppen az itt is többször említett, Han-korra datált T196-ban található (T4n0196p04.0147c17). A brāhmaṇa szó később használt kínai fonetikus átírása poluomen 婆羅門. 
séget és a megértést, ${ }^{82}$ a megszabadulásra vonatkozó tudásom és látásom tökéletesedett: ez a négy végső (igazság).

Ezen születésem után több már nem lesz, végleg elszakadtam a világtól, (számomra) nem lesz többé bánat és szenvedés."

A legtöbb forrás szerint a Dharma-kerék megforgatása mind a négy igazságra (si di 四諦) vonatkozóan háromszor történik meg, nem kivétel ez alól a T109 sem, ezért említi a szöveg a 12 'menetet' (xing 行 [K6, K8], xingxiang 行相 [K11], zhong 種 [K14] vagy shi 事 [K1]). Itt ugyanakkor mintha egy múlt-jelen-jövő hármasságról lenne szó, és nem a máshol inkább megfigyelhető kijelentő (shizhuan 示轉), buzdító (quan zhuan 勸轉), illetve bizonyító jellegü (zheng zhuan 證轉) megforgatásról. ${ }^{83}$ A K1-gyel ellentétben a K6-ban a 'soha korábban nem hallott tanítás' (ben suo wei ceng wen fa 本所未曾 聞法) mindig ugyanabban az alakban szerepel, nem a múlt, jelen és jövő összefüggésében. A K6-ban, a K8-ban és a K10-ban a négy igazság felismerésének és megvalósításának következménye is mindig ugyanaz: a látás vagy 'szem' (yan 眼, p. cakkhu, sz. cakṣus), a tudás (zhi 智, p. ñāna, sz. jñāna), a világosság (ming 明, p. āloko, sz. āloka) és a felébredés (jue 覺, sz. buddhi) ${ }^{84}$ létrejötte vagy létrehozása (sheng 生, p. udapādi, sz. utpanna, udapāsi), a K8-ban mindez kiegészül még a tisztasággal (jing 淨) és a bölcsességgel (hui 慧).

A Dharma-kerék megforgatásának képessége egyedül a Buddhához (illetve más buddhákhoz) kötött, sem az emberi, sem pedig az egyéb világokban nem képes erre senki (suo bu neng zhuan 所不能轉), ezt mutatja például a következő passzus, amelyben alapvetően ugyanazok a szereplők, mint a fenti T109-es idézetben:

„A Tathāgata által elmagyarázott négy nemes igazságot valaki felfogta a tömegben, így a Tathāgata megforgatta a Dharma-kereket. A szerzetesek, a brāhmaṇák, Māra, Māra-deva, devák vagy az emberek világában senki nem képes megforgatni."

82 A fegyelem, meditáció és bölcsesség hármassága (jie, ding, hui 戒定慧) egy általános hármasság (Soothill-Hodous 1977: 239). Vö. Dessein 2007: 17.

84 A páli eredetiben a tudásra vonatkozó további két kifejezés jelenik meg (pañ̃nā, vijjā), de a buddhi nem. 
若如來說四聖諦, 眾中有覺悟者, 如來則為轉法輪。沙門、婆 羅門、魔、若魔天、天及世間人所不能轉。85

A különféle korai irányzatok közül a sarvāstivādinok és a vaibhāṣikák vélték úgy, hogy csak egy másik ember felébredése lehet a Dharma kerekének megforgatása, így a mahāsāmghikákkal ellentétben szerintük a bodhi fa alatti megvilásodás után mondott egyéb beszédek nem kapcsolhatók ezzel közvetlenül össze. ${ }^{86}$

\subsection{A beszéd hatása}

K1/e. 佛說是時, 賢者阿若拘鄰等及八千姟天皆遠塵離垢，諸法 眼生。其千比丘漏盡意解, 皆得阿羅漢, 及上諸習法應當盡者, 一切皆轉。

眾祐法輪聲三轉, 諸天世間在法地者莫不遍聞, 至于第一四天王 、切利天、焰天、㝸術天、不驕樂天、化應聲天, 至諸梵界須臼 遍聞。爾時, 佛界三千日月萬二千天地皆大震動, 是為佛眾祐始 於波羅木奈以無上法輪轉未轉者，照無數度諸天人從是得道。佛 說是已，皆大歡喜。

„Mikor ezeket Buddha elmagyarázta, Kauṇ̣inya bölcs, továbbá 80 ezer millió ${ }^{87}$ istenség, mind megszabadult a (világra jellemző) szennyeződésektől és tisztátalanságoktól, és Dharma-szemük keletkezett. A (jelen lévő) ezer szerzetes szennyeződései véget értek, elméjük megszabadult, mind arhattá váltak, továbbá megértették, hogy »minden, ami okkal keletkező dharma, annak véget is kell érnie, minden forgásban van «. ${ }^{88}$

85 Dharmaguptakavinaya, Sifen lü 四分律, T22n1428p0788b20-22, vö. Dessein 2007: 26. n.51. Több tucat hasonló példát lehetne idézni még a kínai kánonból (például T01n0001p0016a09-11, T03n0189p0644c17-20).

87 Dessein 2007: 36-37.

87 A kínai szövegben 8000 gai szerepel, a gai 姟 pedig általában tízmillió (máskor a szanszkrit ayuta [ayouta 阿由他, ayuduo 阿廋多] vagy nayuta [nayouta 那由他, nayuduo 那属多, nayouduo 那由多] átírása szerepel helyette. Hozzá kell tenni, hogy sem a gai, sem pedig a szanszkrit kifejezések nem egyértelműek matematikailag.

Ez az alapvető buddhista igazság sem az itt vizsgált kínai változatokban, sem pedig a szanszkrit verziókban nem található meg, a T109-n kívül csak a páli változatban szerepel Koṇdañña (aki a páli szövegben az első megtérített személy) által kimondott, 
Mikor a Mindenek-jótevőjének [Bhagavat] Dharma-kereke háromszor körbefordult, nem volt olyan hely az égi és földi világban, ahol a hangja ne hallatszódott volna. (Hangja) eljutott egészen az első Négy égi királyig, a 33 istenségig, a Yama-égig, a Tușita-égig, a Nirmāṇaratiégig és a Paranirmitavaśavarti-égig, ${ }^{89}$ egészen a brahmavilágokig egyetlen pillanat alatt szétterjedt. Ekkor a buddhavilágok 3000 napja és holdja, 12000 ege és földje mind rendkívüli módon megrendült, mindez amiatt, mert a Mindenek-jótevője, Buddha a felülmúlhatatlan Dharmakerék révén elsőként forgatta meg a meg-nem-forgatottat Benaresben, megvilágítva ${ }^{90}$ a végtelen számú istent és embert, akik innen kiindulva nyerték el a megszabadulást.

Miután Buddha mindezeket elmagyarázta, mindannyian rendkívüli módon örvendtek."

A szövegben említett Kaundịinya (Āruòjūlín 阿若拘鄰, Āruò Jiāo chénrú 阿若 憍陳如, Āruò Jiāochénnà 阿若憍陳那) annak az öt aszkétának (pañcavaggiyo bhikkhū) egyike, akikkel együtt Buddha a szélsőséges aszkézist gyakorolta. Az öt aszkéta páli neve: (Aññāsi) Koṇụañña, Bhaddiya, Vappa, Assaji, Mahānāma. ${ }^{91}$ A szövegbool magából nehéz lenne megmagyarázni, hogy az öt aszkéta közül miért éppen Koṇ̣añña az, aki elsőként ismerte fel a buddhai tanítás lényegét, de a későbbi hagyomány is egységesen őt nevezi meg ekként. ${ }^{92}$ Az egyik magyarázatként említhető, hogy bizonyos változatokban (például Lalitavistara) Kauṇdinya az, aki nem ért egyet négy aszkétatársával abban, hogy a feléjük közeledő Buddhát ne megfelelően köszöntsék (bár ezt nem teszi szóvá), vagyis ezen narratíva szerint ő az, aki már a kezdetektől fogva

tehát felismert és magáévá tett tétel (,yam kiñ-ci samudaya-dhammaṃ, sabbaṃ tam nirodha-dhamman" ti).

Sastri (1938: 492) azonosítása: az 'Önzetlen öröm istenei' [paranirmitavaśavartidevā], de Mueller szerint a Nirmāṇarati felel meg a 不驕樂天 kifejezésnek (ami alternatív írásmódja az egyébként gyakrabban használt 不憍樂天-nek). Smith (27. n.79) szerint is a 不驕樂天 és a Nirmāṇarati azonosak, míg a 化應聲天 jelenti a paranirmitavaśavartidevāt. Ezek a mások, illetve a saját teremtésükben gyönyörködő istenekre vonatkoznak.

90 Az analógia a páli változat lezáró részéből származik (A páli fordítócsoport 2011): „mérhetetlen és pompázatos ragyogás támadt a világban, felülmúlva az istenek fenségét" (a-ppamāṇo ca ulāro obhāso loke pātur-ahosi, atikkamma devānam devânubhāvan).

91 Körtvélyesi 2018: 170. n. 416.

92 Dessein 2007: 34-35. 
a legkevésbé ítélte el azt, hogy Gautama felhagyott az aszketikus praxissal. A közvetlen előzmények mellett több egyéb motívum is található más szövegekben, amelyek különlegessé teszik Kauṇ̣inyát: a hagyomány szerint Gautama születésekor (fiziognómiai ismereteinek köszönhetően) a legfiatalabbként volt jelen a nyolc udvari jós között, és ő volt az egyetlen, aki nem számolt azzal a lehetőséggel, hogy a gyermek világhódító király lesz, továbbá a másik négy aszkétához képest, akik egyébként az udvari jósok közül négynek a gyermekei voltak, idősebb volt. ${ }^{93}$

A T109 Kauṇịinya mellett említi azt a több millió istenséget $($ tian 天 $=$ deva), akik Buddha beszédének hatására megszabadultak. Ez a motívum a legkevésbé sem egyedülálló, megtalálható a legtöbb kínai verzióban (K6, K8, $\mathrm{K} 10, \mathrm{~K} 12, \mathrm{~K} 13$ ), amelyek ugyanakkor szerényebben 80 ezer istenségröl ( $b a$ wan tianzhong 八萬天眾, illetve ba wan zhutian 八萬諸天, ba wan tianzi 八萬天子) szólnak, akik Kauṇdinyával együtt megtisztultak a szennyeződésektől, és akiknek szintén megnyílt a Dharma-szemük. ${ }^{94}$ Valójában nem igazán érthető a T109 késeisége melletti érv, amely arra alapoz, hogy a beszéd bevezetőjében a szokásos öt aszkétához képest isteni lények sokasága is megjelenik, mivel a beszéd végén lényegében minden változatban jelen vannak az égi lények, így a T109 mindössze ezt a végállapotot vetítette vissza a beszéd elejére.

\section{A T109 és a T196 viszonya}

Jelen tanulmányban a történeti Buddha első beszédének, a Dhammacakkappavattana-sutta egyik legkorábbi kínai verzióját vizsgáltam meg. A hagyomány az iráni (pártus) származású An Shigaónak (2. sz.) tulajdonítja a fordítást, de a kutatók többsége úgy véli, hogy ez a szuttában használt terminológia alapján nem valószínü. Annak ellenére, hogy a fordítás korai, a téma talán legkiválóbb ismerője, Anālayo úgy döntött, hogy kétrészes és mintegy 70 oldalas tanulmányában nem foglalkozik a szöveggel.

A szöveg vizsgálata során arra lettem figyelmes, hogy a T109-nek számos terminológiai átfedése van a szintén korai T196-ban szereplő verzióval, amely

93 Buswell-Lopez 2014: 24-25; Tan 2002/2010: 2-3.

94 T02n0099p0104a09, T02n0110p0504b07, T24n1450p0128a10, T23n1435p0448c1415, T24n1451p0292b29, T26n1537p0480a14. 
Zhongbenqi jing 中本起經 [Madhyama-ityukta sūtra] címü szövegben szerepel, és amelynek két fordítója volt: Tanguo 曇果 és az iráni (szogd) származású Kang Mengxiang 康孟詳 (2. sz.). A pontos, illetve hozzávetőleges átfedések a következők:

\begin{tabular}{|c|c|c|}
\hline & T109 & T196 \\
\hline két véglet & 有二事墮邊行 & 行有二事為墮邊際 \\
\hline egyik véglet & 念在貪欲, 無清淨志 & 念在色欲, 無清淨志 \\
\hline másik véglet & 猗著身愛, 不能精進 & 猗愛著貪, 不能清志行 \\
\hline négy igazság & 苦、習、盡、道 & 苦, 苦習, 苦習盡, 道 \\
\hline szenvedés 1. & 生老苦、病苦 & 生苦、老苦、病苦 \\
\hline szenvedés 2. & 憂、悲、惱苦 & 憂、悲、惱苦 \\
\hline szenvedés 3 . & 怨憎會苦 & 怨憎會苦 \\
\hline szenvedés 4. & 所愛別苦 & 恩愛別苦 \\
\hline szenvedés 5. & 要從五陰受盛為苦 & 要因五陰受盛為苦 \\
\hline nyolcrétü ösvény 1. & 正見、正思、正言、正行、 & 正見、正利、正言、正行 \\
\hline nyolcrétü ösvény 2. & 正命、正治、正志、正定 & 正命、正治、正志、正定 \\
\hline beszéd hatásal. & 漏盡意解 & 漏盡意解 \\
\hline beszéd hatása 2. & 以無上法輪轉未轉者 & 以無上法輪轉未轉者 \\
\hline
\end{tabular}

A T109 és a T196 két különböző ind eredeti kínai fordítása, ugyanakkor a témájuk hasonló, és a bennük szereplö, többször is teljesen egyedi terminológiai átfedés a várható átlag felett van. Számos olyan kifejezés található bennük, amelyek sehol máshol nincsenek meg: a második véglet csak ebben a két müben fogalmazódik meg az aszkézis explicit kifejtése nélkül, illetve nagyon hasonló szavakkal (yi 猗, zhuo 著, $a i$ 愛); a nyolcrétủ ösvény felsorolásának csak ebben a két müben szerepel a zhengzhi 正治 mint a helyes törekvés megfelelője; valamint a lezárásnál csak ebben a két müben találkozunk ,a felülmúlhatatlan Dharma-kerékkel elsőként forgatta meg a megnem-forgatottat” (以無上法輪轉未轉者) kifejezéssel. Ha mindehhez hozzáteszünk néhány további, általánosabb, de azért jellemzö terminológiai azonosságot (például nirvána $=$ nihuan 泥洹, bhagavat $=$ zhongyou 眾祐), valamint elfogadjuk, hogy mindkét szöveg i. sz. 200 környékén keletkezett, akkor feltételezhetjük, hogy a fordítók között lehetett valamilyen kapcsolat.

A gondolatmenetet folytatva, amennyiben tehát elfogadjuk, hogy a T109 korai, de nem az iráni származású An Shigao fordította, továbbá megvizsgáljuk, hogy a hasonló témájú, de nyilvánvalóan más eredetiből készült T196 milyen mértékben hasonlít a terminológiát illetően, akkor ennek egyik lehetsé- 
ges magyarázata az lehet, hogy a T109-et a szintén korai és szintén iráni Kang Mengxiang (fl. 194-210) fordította. ${ }^{95}$ Míg An Shigaónak előszeretettel tulajdonítottak újabb és újabb műveket (az eredeti 34-ből néhány évszázad alatt 179 lett), addig Kang Mengxiang nevét elsősorban két müvel (T184: Xiuxing benqi jing 修行本起經; T196: Zhong benqi jing 中本起經) kapcsolták össze, ${ }^{96}$ ráadásul ez a kettő valójában egy hosszabb mü két része, továbbá mindkét fordítást egy-egy indiai szerzetessel (Zhu Dali 笂大力 [Mahābala?], Zhu Tanguo 䇥昙果 [Dharmaphala?]) együtt készítette. ${ }^{97}$ A nekik tulajdonított müvek számát és ezzel összefüggésben népszerüségüket tekintve Kang Mengxiang és An Shigao egymás ellentétei.

Ez a hipotézis megmagyarázná azt, hogy miért állítja számos kutató, hogy ez a munka nem illik An Shigao fordítói oeuvre-jébe. An Shigaót és Kang Mengxiangot kortárs jellegük (i. sz. 200 körül) és iráni származásuk egymáshoz hasonlóvá tehette, ugyanakkor az, hogy An Shigao jóval népszerübb volt Kang Mengxiangnál, fontos szerepet játszhatott abban, hogy a T109 fordítását nem a valódi szerzőnek tulajdonította az utókor.

\section{Elsődleges forrás}

Takakusu Junjirō 高楠順次郎 - Watanabe Kaigyoku 渡辺海旭 (eds.) 1924-32. Taishō shinshū daizōkyō 大正新脩大蔵経. 85 vols. Tōkyō: Taishō Issaikyō Kankōkai. [Online version: SAT Daizōkyō Text Database (SAT 大正新脩大蔵経テキストデ ータベース). 2015 version. University of Tokyo, http://21dzk.1.u-tokyo.ac.jp/SAT/ (utoljára megtekintve: 2019.07.20.)]

\section{Felhasznált másodlagos szakirodalom}

A páli fordító csoport 2011. „SN 56.11 Dhammacakkappavattana Sutta. 1. A Dharma kerekének forgásba hozása." Online elérhetőség: http://a-buddha-ujja.hu/Szutta/Samyutta56-11-cs1 (utolsó megtekintés: 2019.07.01.)

95 Nattier 2008: 102-109.

96 Nattier (2008: 108-109) kétségbe vonja, hogy a T184-et valóban Kang Mengxiang fordította, de a T196 fordítását vele kapcsolja össze. További kettőben (T02n0137, T04n0197) szerepel még fordítóként a neve.

97 Durt 2008 [2010]: 122, Zürcher 1991: 299 [2013: 444]. 
Anālayo 2012. „The Chinese Parallels to the Dhammacakkappavattana-sutta (1).” Journal of the Oxford Centre for Buddhist Studies 3: 12-46. [Online elérhetőség: http://www.jocbs.org/index.php/jocbs/article/view/25/39, utolsó megtekintés: 2019. június 28.]

Anālayo 2013. „The Chinese Parallels to the Dhammacakkappavattana-sutta (2).” Journal of the Oxford Centre for Buddhist Studies 5: 9-41. [Online elérhetőség: http://jocbs. org/index.php/jocbs/article/view/53/85, utolsó megtekintés: 2019. június 28.]

Anālayo 2017. „Dhammacakkappavattana-sutta”, In: K. T. S Sarao - J. D. Long (eds.): Encyclopedia of Indian Religions, Buddhism and Jainism. Dordrecht: Springer, 372374. https://doi.org/10.1007/978-94-024-0852-2_905

Bareau, André 1963. Recherches sur la biographie du Buddha dans les Sutrapitaka et les Vinayapitaka anciens. Vol. I : De la quête de l'Éveil à la conversion de Sâriputra et Maudgalyâyana. [PEFEO, vol. 53.] Paris: École française d'Extrême-Orient.

Bodhi (Bkikkhu) 2000. The Connected Discourses of the Buddha: A Translation of the Samyutta Nikāya. Boston: Wisdom Publications.

Buswell, Robert E., Jr. - Donald S. Lopez, Jr. (eds.) 2014. The Princeton Dictionary of Buddhism. Princeton, NJ: Princeton University Press. https://doi.org/10.1515/97814 00848058

Dessein, Bart 2007. „The First Turning of the Wheel of the Doctrine - Sarvāstivāda and Mahāsāghika Controversy." In: Ann Heirman - Stephan Peter Bumbacher (eds.): The Spread of Buddhism. Leiden-Boston: Brill, 15-48. https://doi.org/10.1163/ej.97890 04158306.i-474.6

Dharmachakra Translation Committee 2013. The Play in Full: Lalitavistara. New York: 84000.

Durt, Hubert 2008 [2010]. „Early Chinese Buddhist translations - Quotations from the early translations in anthologies of the sixth century." Journal of the International Association of Buddhist Studies 31/1-2: 119-139.

Forte, Antonino 1995. The Hostage An Shigao and his Offspring: an Iranian Family in China. Kyoto: Scuola di Studi sull'Asia Orientale.

Horner, I. B. 1951/1982. The Book of the Discipline (Vinaya Pitaka). Vol. IV. (Mahāvagga). London: Pali Text Society.

Körtvélyesi Tibor 2018. A páli kánon egyes rétegei - szövegtörténeti és doktrinális vizsgálódások. ELTE BTK, Nyelvtudományi Doktori Iskola, PhD-disszertáció.

Monier-Williams, Monier [rev. by E. Leumann, C. Cappeller et al.] 1899. A SanskritEnglish Dictionary: Etymologically and Philologically Arranged with Special Reference to Cognate Indo-European languages. Oxford: Clarendon Press.

Nattier, Jan 2008. A Guide to the Earliest Chinese Buddhist Translations: Texts from the Eastern Han 東漢 and Three Kingdoms 三國 Periods. Tokyo: The International Research Institute for Advanced Buddhology, Soka University.

Sastri, N. A. 1938. „The First Sermon of the Buddha.” New Indian Antiquary 1/8: 473-492.

Smith, Norman J. 2001. „The 17 Versions of the Buddha's First Discourse.” [Online elérhetöség: https://ia600304.us.archive.org/22/items/The17VersionsOfTheBuddhasFirstDiscour se/dhammacakka.pdf; utolsó megtekintés: 2019.07.06.] 
Soothill, William Edward - Hodous, Lewis 1977. A Dictionary of Chinese Buddhist Terms: with Sanskrit and English Equivalents and a Sanskrit-Pali Index. Delhi Varanasi - Patna: Motilal Banarsidass [Eredeti kiadás: K. Paul, Trench, Trubner \& Co., 1937].

Tan Piya 2002/2010. „Dhammacakka Pavattana Sutta.” Online elérhetőség: http://www. themindingcentre.org/dharmafarer/wpcontent/uploads/2009/12/1.1-Dhammacakka-Pa vattana-S-s56.11-piya.pdf; utolsó megtekintés: 2019.07.01.

Vekerdi József 1989. Buddha beszédei. Budapest: Helikon Kiadó.

Zacchetti, Stefano, 1997. „Un problema di critica testuale nel Foshuo zhuan falun jing (T109) attribuito ad An Shigao." Annali di Ca' Foscari, Rivista della Facolta di Lingue e Letterature Straniere de O'Universita di Venezia 36/3: 381-395.

Zacchetti, Stefano 2010. „Defining An Shigao's 安世高 Translation Corpus: The State of Art in Relevant Research.”Xiyu Lishi Yuyan Yanjiu Jikan 西域歷史語言研究集刊 3: 249-270.

Zürcher, Erik 1977. „Late Han Vernacular Elements in the Earliest Buddhist Translations.” Journal of Chinese Language Teachers Association 12: 177-203. [Repr. in Jonathan A. Silk (ed.): Buddhism in China. Collected Papers of Erik Zürcher. Leiden-Boston: Brill, 27-61.]

Zürcher, Erik 1991 [2013]. „A New Look at the Earliest Chinese Buddhist Texts.” In: Koichi Shinohara - Gregory Schopen (eds.): From Benares to Beijing: Esays on Buddhism and Chinese Religion. Oakville: Mosaic Press, 277-304. [Repr. in: Jonathan A. Silk (ed.): Buddhism in China. Collected Papers of Erik Zürcher. Leiden-Boston: Brill, 419-446.]

Zürcher, Erik 2007. The Buddhist Conquest of China. The Spread and Adaptation of Buddhism in Early Medieval China. [Sinica Leidensia, Vol. 11.] Leiden: Brill. [Eredeti kiadás: 1959. Leiden: Brill. 2 vols.] 